\title{
Analisis Kelayakan Finansial Usaha Pengolahan Kelapa Parut Kering (Desiccated Coconut) (Studi Kasus Pada PT. Gailolo Coco Industri di Desa Luari Kecamatan Tobelo Utara)
}

\author{
Haryati La Kamisi ${ }^{1}$ dan Linda Umasugi ${ }^{1 凶}$ \\ ${ }^{1}$ Staf Pengajar Prodi AGRIBISNIS Universitas Muhammadiyah Maluku Utara, Ternate. Indonesia. \\ Email : dinati.la@gmail.co, umasugi_linda@gmail.com
}

\author{
У Info Artikel: \\ Diterima : 27 Mei 2018 \\ Disetujui : : 13 Juni 2018 \\ Dipublikasi : 26 Juli 2018 \\ Artikel Penelitian \\ Keyword: \\ Analisis kelayakan, kelapa parut kering, \\ usaha pengolahan \\ $\triangle$ Korespondensi:
Linda Umasugi
Universitas Muhammadiyah Maluku Utara,
Ternate. Indonesia. \\ Email: umasugi_linda@gmail.com
}

\begin{abstract}
Abstrak. Kelapa merupakan salah satu penghasil bahan makanan yang sangat penting dalam kehidupan rakyat Indonesia. Hal ini dapat dilihat dari kenyataan bahwa $75 \%$ dari minyak nabati dan 8\% dari konsumsi protein bersumber dari kelapa. Salah satu hasil dari bagian kelapa yaitu daging kelapa dapat dimanfaatkan sebagai kelapa parut kering (desiccated coconut).Penelitian ini bertujuan untuk menganalisis kelayakan finansial usaha pengolahan kelapa parut kering pada PT.Gailolo Coco IndustridiDesa Luari Kecamatan Tobelo Utara dengan menggunakan kriteria investasi.Hasil analisis kelayakan finansial menunjukkan bahwa usaha pengolahan kelapaparut kering pada PT.Gailolo Coco Industrilayak dan menguntungkan dengan nilai NPV yang positif, sebesar Rp.4,602,431,497.25; nilai Net B/C ratio sebesar 2,91; nilai IRR sebesar 68\% atau lebih besar dari suku bunga bank yang berlaku saat ini yaitu 9\%; serta nilai PBP yaitu 7 Bulan 15 Hari.
\end{abstract}

\section{PENDAHULUAN}

Tanaman kelapa (Cocos nucifera L) merupakan tanaman serba guna, yang keseluruhan bagiannya dapat dimanfaatkan bagi kehidupan manusia dan menghasilkan keuntungan. Oleh karena itu kelapa mempunyai arti yang sangat penting bagi kehidupan dan perekonomian di Indonesia. Meskipun begitu, kelapa sering mengalami ketidakstabilan baik dari jumlah maupun harganya. Pada saat kelapa melimpah, harganya akan mengalami penurunan sampai rendah sekali. Mengakibatkan petani mengalami kerugian, sehingga perlu pemanfaatan yang optimal dari buah kelapa agar dapat meningkatkan nilai jual dari buah kelapa. Di samping itu upaya tersebut harus dapat menjamin daya simpan maupun kegunaannya, salah satunya adalah diawetkan menjadi kelapa parut kering.

Produk kelapa parut kering sudah lama digunakan oleh konsumen di Indonesia mengingat Indonesia memiliki sumber daya tanaman kelapa yang melimpah. Kelapa parut kering diperoleh dengan mengeringkan kelapa parutan sampai kadar air 3,5\% dan kadar minyak tidak kurang dari $68 \%$. Warna kelapa parut kering yang diinginkan adalah putih alami dengan aroma atau rasa yang tidak berubah sehingga dalam pemanfaatannya dapat dihasilkan produk dengan kualitas yang baik. Kelapa parut kering dapat dimanfaatkan untuk pembuatan roti, biskuit, manisan ataupun dapat diambil santannya.

Usaha pengolahan kelapa parut keringmerupakan usaha yang memerlukan ketersediaan bahan baku kelapa secara kontinyu, sementara disisi lain pelaku usaha secara ekonomis harus profitable dan sustainable, sehingga perlu dilakukan analisis usaha untuk mengetahui dan menilai apakah usaha tersebut menguntungkan dan layak untuk keberlanjutannya di masa yang akan datang. Berdasarkan kondisi tersebut sehingga penulis tertarik untuk melakukan penelitian dengan judul: “Analisis Kelayakan Finansial Usaha Pengolahan Kelapa Parut Kering (Desiccated Coconut) Pada PT.Gailolo Coco Industri di Desa Luari Kecamatan Tobelo Utara". 
Tujuan penelitian ini adalah untuk menganalisis kelayakan finansial usaha dengan menggunakan kriteria investasi dari usaha pengolahan kelapa parut keringpada PT.Gailolo Coco Industridi Desa Luari Kecamatan Tobelo Utara.

\section{METODE PENELITIAN}

Penelitian ini berlokasi di PT.Gailolo Coco Industri di Desa Luari Kecamatan Tobelo Utara, yang ditentukan secara sengaja (purposive) karena lokasi tersebut merupakan salah satu sentra pengolahan kelapa di Kecamatan Tobelo Utara.

Jenis data yang digunakan dalam penelitian ini adalah data primer dan sekunder. Data primer diperoleh secara langsung dari sumber datanya melalui observasi, wawancara, dan kuesioner. Data sekunder diperoleh dari berbagai sumber yang telah ada seperti Biro Pusat Statistik (BPS), buku, laporan, jurnal, dan lain-lain yang berkaitan dengan penelitian ini.

Metode analisis data pada penelitian ini yang digunakan untuk menentukan kelayakan usaha pengolahan kelapaparut kering meliputi:

a. NPV (Net Present Value)adalah selisih antara present value dari arus benefit dikurangi present value dari arus biaya (Pudjosumarto, 1991). Kriteria ini mengatakan bahwa proyek akan dipilih apabila NPV $>0$. Penentuan nilai NPV secara matematis (Shinta, 2011)dirumuskan sebagai berikut:

$$
\mathrm{NPV}=\sum_{t=1}^{n} \frac{(B t-C t)}{(1+i)^{t}}
$$

Dimana: $\mathbf{B t}=$ Benefit pada tahun ke-t

$$
\begin{aligned}
\mathrm{Ct} & =\text { Biaya pada tahun ke- } \mathrm{t} \\
\mathrm{t} & =\text { lamanya waktu investasi } \\
\mathrm{i} & =\text { tingkat bunga }
\end{aligned}
$$

Jika: NPV $>0=$ usaha layak

$\mathrm{NPV}=0=$ usaha impas

$\mathrm{NPV}<0=$ usaha tidak layak

b. Net B/C Ratio (Net Benefit/Cost Ratio) adalah penilaian yang dilakukan untuk melihat tingkat efisiensi penggunaan biaya berupa perbandingan jumlah nilai bersih sekarang yang positif dengan jumlah nilai bersih sekarang yang negatif (Gray, 1997). Suatu usaha layak dan efisien untuk dilaksanakan jika nilai Net B/C > 1, yang berarti manfaat yang diperoleh lebih besar dari biaya yang dikeluarkan. Secara matematis Net B/C ratio(Pudjosumarto, 1991) dirumuskan sebagai berikut:
Net B/C Rasio $=\frac{\sum_{i=1}^{n} \frac{B t}{(1+i)^{t}}}{\sum_{i=1}^{n} \frac{C t}{(1+i)^{t}}}$

Dimana:

$$
\begin{aligned}
& \mathrm{Bt}=\text { Bebefit pada tahun ke-t } \\
& \mathrm{C} \mathrm{t}=\text { Biaya pada tahun ke- } \mathrm{t} \\
& \mathrm{i}=\text { tingkat bunga yang berlaku } \\
& \mathrm{t}=\text { jangka waktu proyek } \\
& \mathrm{n}=\text { umur proyek }
\end{aligned}
$$

Jika: $\mathrm{B} / \mathrm{C}>1$ = Layak

$\mathrm{B} / \mathrm{C}<1$ = Tidak Layak

c. IRR (Internal Rate of Return) adalah nilai discount rate (I) yang membuat NPV suatu usaha sama dengan nol atau dengan perkataan lain IRR menunjukkan present value (benefit) sama dengan present value (cost). IRR digunakan untuk mencari tingkat bunga yang menyamakan Bt pada nilai sekarang dengan $\mathrm{Ct}$ pada nilai sekarang di masa-masa mendatang (Soekartawi, 2006). Penggunaan Investasi akan layak jika diperoleh IRR yang persentasenya lebih besar dari tingkat suku bunga bank yang ditentukan, karena usaha berada dalam keadaan yang menguntungkan. Secara matematis IRR dirumuskan sebagai berikut (Pudjosumarto, 1991):

$$
\text { IRR }=i_{1}+\frac{N P V_{1}}{N P V_{1}-N P V_{2}}\left(i_{2}-i_{1}\right)
$$

Dimana:

$\mathrm{NPV}_{2}=$ Perhitungan NPV positif mendekati nol dengan bunga modal sebesar $i_{1}$ persen

$\mathrm{NPV}_{1}=$ Perhitungan NPV negatif mendekati nol dengan bunga modal sebesar $i_{2}$ persen

$\mathbf{i}_{1}=$ Discount factor (DF) pertama, tingkat bunga yang menghasilkan NPV positif

$\mathrm{i}_{2}=$ Discount factor (DF) kedua, tingkat bunga yang menghasilkan NPV negatif

Jika: IRR $>$ Sosial Discount Rate $=$ usaha layak IRR $<$ Sosial Discount Rate = usaha tidak layak

d. PBP (Payback Period) adalah tingkat pengembalian investasi diartikan sebagai jangka waktu kembalinya investasi yang dikeluarkan melalui keuntungan yang diperoleh dari suatu usaha Gray (1997).Semakin cepat tingkat pengembalian investasi maka 
usaha layak untuk diusahakan dan sebaliknya semakin lambat investasi yang digunakan itu dikembalikan maka usaha tidak layak untuk diusahakan. Secara matematis PBP dirumuskan sebagai berikut Pudjosumarto (1991):

$$
\mathrm{PBP}=\frac{I}{A_{b}}
$$

Dimana: $\mathbf{I}$ = besarnya biaya investasi yang diperlukan

$A_{b}=$ benefit bersih yang dapat diperoleh setiap tahunnya

\section{HASIL DAN PEMBAHASAN}

\subsection{NPV (Net Present Value)}

Nilai Net Present Value (NPV) menunjukkan nilai bersih usaha pada akhir umur ekonomisnya dengan menggunakan nilai suku bunga yang berlaku saat ini. Nilai NPV diperoleh dari selisih antara Present Value Cash Flowdengan total investasi. Perhitungan nilai NPV pada usaha pengolahan tepung kelapamenunjukkan nilai positif, yaitu Rp.4,602,431,497.25. Hal ini menunjukkan bahwa usaha pengolahan tepung kelapa layak dijalankan karena nilai NPV > yang artinya usaha tersebut dapat menghasilkan cash inflow dengan persentasi lebih besar dibandingkan opportunity cost modal yang ditanamkan (Rangkuti, 2004).

\subsection{Net B/C Ratio (Net Benefit/Cost Ratio)}

Net B/C Ratio atau analisis rasio keuntungan merupakan perbandingan antara tingkat keuntungan (benefit) bersih dari tahun-tahun yang bersangkutan yang telah di-present value-kan (pembilang/bersifat positif (+)) dengan biaya bersih dalam tahun dimana Bt - Ct (penyebut/bersifat negatif (-)) yang telah di-present value-kan, yaitu biaya kotor <benefit kotor. Perhitungan nilai Net B/C Ratio usaha pengolahan tepung kelapa pada penelitian ini sebesar 2,91 yang berarti bahwa biaya yang dikeluarkan sebesar Rp. 1,00 akan memberi keuntungan sebesar Rp. 2,91. Nilai ini menunjukkan bahwa usaha pengolahan tepung kelapa layak dijalankan, dan ini sesuai dengan pendapat Rahardi dan Hartanto (2003), yang menyatakan suatu usaha dikatakan layak dan memberikan manfaat apabila Net B/C Rasio > 1, semakin besar nilai Net B/C maka semakin besar pula manfaat yang diperoleh dari usaha tersebut.

\subsection{IRR (Internal Rate of Return)}

Internal Rate of Return (IRR) menunjukkan kemampuan suatu usaha untuk menghasilkan returns atau tingkat keuntungan yang dapat dicapainya. Hasil perhitungan nilai IRR usaha pengolahan tepung kelapa yaitu $68 \%$ dan nilai tersebut jauh lebih besar dari bunga bank yang berlaku yaitu $9 \%$. Hal ini menunjukkan bahwa usaha pengolahan tepung kelapafeasible dan layak dijalankan karena menghasilkan tingkat pengembalian lebih besar dari suku bunga yang berlaku secara umum.

\subsection{PBP (Payback Period)}

Payback Period (PBP) menunjukkan jangka waktu kembalinya investasi yang dikeluarkan melalui keuntungan yang diperoleh dari suatu usaha. Semakin cepat tingkat pengembalian investasi maka usaha layak untuk diusahakan dan sebaliknya semakin lambat investasi yang digunakan itu dikembalikan maka usaha tidak layak untuk diusahakan.Hasil perhitungan nilai PBP usaha pengolahan tepung kelapa yaitu 7 bulan 15 hari. Hal ini menunjukkan bahwa usaha pengolahan tepung kelapafeasible dan layak dijalankan karena menghasilkan tingkat pengembalian investasi yang lebih cepat yaitu kurang dari setahun.

\section{PENUTUP}

\subsection{Kesimpulan}

Usaha pengolahan kelapa parut kering pada PT.Gailolo Coco IndustridiDesa Luari Kecamatan Tobelo Utara menguntungkan dan layak dijalankan. Analisis kelayakan usaha menunjukkan nilai NPV yang positif, yaitu sebesar Rp. 4,602,431,497.25.; nilai Net B/C Ratio yaitu sebesar 2,91; nilai IRR sebesar $68 \%$ atau lebih besar dari bunga bank yang berlaku yaitu 9\%; serta nilai PBP yaitu 7 Bulan 15 Hari.

\subsection{Saran}

Dalam rangka menjaga kestabilan harga pada saat kelapa melimpah maka perlu pemanfaatan yang optimal dari buah kelapa menjadi produk kelapa parut kering agar dapat meningkatkan nilai jual dari buah kelapa sehingga dapat menghasilkan keuntungan bagi petani kelapa. 


\section{DAFTAR PUSTAKA}

Adawyah R. 2007. Pengolahan dan Pengawetan Ikan. PT. Bumi Aksara. Jakarta.

Gray C. 1997. Pengantar Evaluasi Proyek. Edisi Kedua. PT. Gramedia Pustaka Utama. Jakarta.

Pudjosumarto M. 1991. Evaluasi Proyek: Uraian Singkat dan Soal-Jawab. Liberty. Yogyakarta.

Shinta A. 2011. Ilmu Usahatani. UB-Press. Malang.

Soekartawi. 2006. Analisis Usahatani. UI-Press. Jakarta.

Sugiyono. 2007. Statistika untuk Penelitian. CV. Alfabeta. Bandung.

Rahardi F, Hartanto R. 2003. Agribisnis Peternakan. Penebar Swadaya. Jakarta

Rangkuti F. 2012. Study Kelayakan Bisnis dan Ivestasi. Kompas Gramedia Building. Jakarta.

Warisno. 2003. Budidaya kelapa genjah. Kanisius. Yogyakarta.

Winarno FG. 2008. Kimia Pangan dan Gizi. Ed. Terbaru. M Brio Press. Jakarta.

Zaelanie K, Nurdiani R, Dayuti S. 2004. Teknologi Hasil Perikanan I. Fakultas Perikanan Universitas Brawijaya. Malang. 